\title{
Ataxia and Parkinsonism in a Woman With a VCP Variant and Long-Normal Repeats in the SCA2 Allele
}

Alana E. Kirby, MD, PhD, Virginia Kimonis, MD, and Katie Kompoliti, MD

Neurol Genet 2021;7:e595. doi:10.1212/NXG.0000000000000595

We present the case of a 46-year-old woman with gradually progressive ataxia, parkinsonism, and neuropathy. Symptoms started at age 29 years with speech impairment and difficulty walking. At presentation, she had mild midline ataxia and dysarthria. Left hand rest tremor began at age 33 years. Over the next decade, she developed parkinsonism and lower extremity weakness, which was more prominent than ataxia (Videos 1 and 2 ). Her parkinsonism was responsive to levodopa, and over time, she developed motor fluctuations. She also developed urinary retention and constipation. Medical history was otherwise notable for lumbar radiculopathy, ankylosing spondylitis, elevated anti-nuclear antibodies, migraine, and depression. Current examination reveals appendicular and gait ataxia, dysarthria, parkinsonism (left predominant), bilateral hip flexor weakness and foot drop, length-dependent decrease in pinprick sensation, and hyperreflexia (bilateral Babinski and jaw jerk reflexes). She is adopted and has 2 healthy teenaged sons. She is apparently of European descent but does not know her family history.

On initial workup, very long chain fatty acids and vitamin $\mathrm{E}$ were normal, and human $\mathrm{T}$ lymphotropic virus type I and II testing was negative. Electromyogram/nerve conduction study showed sensorimotor demyelinating neuropathy. MRI of the brain (Figure) showed no cerebellar atrophy or white matter abnormalities. I-123 ioflupane SPECT imaging showed decreased reuptake in the basal ganglia bilaterally. A spinocerebellar ataxia (SCA) trinucleotide repeat panel showed long-normal repeats (31 and 32) in the ATXN2 gene encoding ataxin-2. An ataxia exome panel was unremarkable; later testing showed a heterozygous intronic AAGGG repeat expansion (115 repeats) of the RFC-1 gene encoding replication factor $\mathrm{C}$ subunit 1 . Whole-exome sequencing identified a known pathogenic variant in the $V C P$ gene encoding valosin-containing protein (heterozygous p.R159C c.475C $>\mathrm{T}$ ). There was no evidence of myopathy or Paget disease of bone (PDB).

Valosin-containing protein (VCP) is a ubiquitous enzyme that catalyzes the decomposition of adenosine triphosphate (ATP) into adenosine diphosephate, that is involved in multiple cellular processes including protein degradation. The $\mathrm{R} 159 \mathrm{C}$ variant is associated with autosomal dominant inheritance but variable neurodegenerative phenotypes within and between kindreds; the most common being a combination of inclusion body myopathy and frontotemporal dementia (FTD) with onset around 50-60 years, ${ }^{1}$ but Parkinson disease, ${ }^{2}$ spastic paraplegia, and PDB have also been reported. Of interest, 1 individual in an R159C kindred (genotype unknown) was initially diagnosed with spinocerebellar degeneration, ${ }^{3}$ but we are not aware of other reports of ataxia. Classically, pathogenic variants in VCP have been associated with a combination of myopathy, PDB, and FTD, but these phenotypes have been reported individually as well as in combination with amyotrophic lateral sclerosis (ALS), Parkinson, and Charcot-Marie-Tooth. ${ }^{1,2}$ Penetrance is not well defined because of variability in age at onset.

\author{
Correspondence \\ Dr. Kirby \\ alana_e_kirby@rush.edu
}

MORE ONLINE

Videos

From the Department of Neurological Sciences (A.E.K., K.K.), Rush University Medical Center, Chicago, IL; and Division of Genetics and Genomic Medicine (V.K.), Department of Pediatrics, University of California, Irvine.

Funding information and disclosures are provided at the end of the article. Full disclosure form information provided by the authors is available with the full text of this article at Neurology.org/NG.

The Article Processing Charge was funded by the authors.

This is an open access article distributed under the terms of the Creative Commons Attribution-NonCommercial-NoDerivatives License 4.0 (CC BY-NC-ND), which permits downloading and sharing the work provided it is properly cited. The work cannot be changed in any way or used commercially without permission from the journal. 

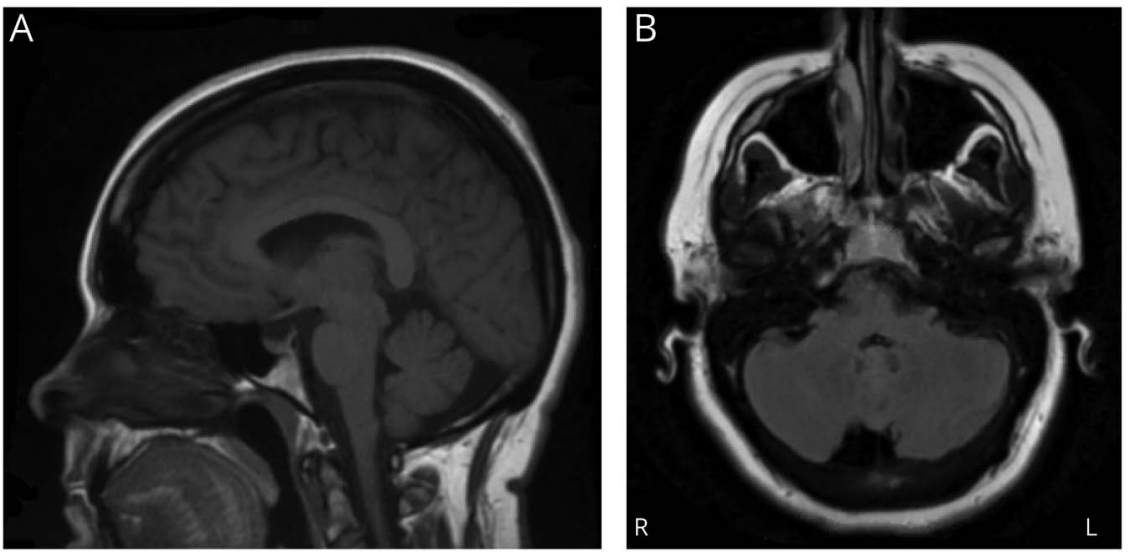

(A) Sagittal and (B) axial T2 fluid attenuated inversion recovery sequence. An incidental arachnoid cyst is present (right of midline). There is minimal cerebellar atrophy.

Pathogenic expansions of CAG repeats in the ATXN2 gene are associated with a variety of neurodegenerative phenotypes that segregate with trinucleotide repeat size. ${ }^{4}$ Repeats $\geq 33$ cause autosomal dominant SCA type 2 (SCA2) with a range of neurodegenerative phenotypes including progressive cerebellar dysfunction, slowed saccades, pyramidal dysfunction, neuronopathy and peripheral neuropathy, as well as levodoparesponsive parkinsonism. Long-normal CAG repeats (30-33 repeats) have been associated with an increased risk of ALS, ${ }^{5}$ as well as progressive supranuclear palsy (30-32 repeats $)^{6}$ and multiple system atrophy (29-31 repeats). ${ }^{7}$ Autosomal recessive pattern of inheritance has been reported in a Japanese woman with two 31-repeat alleles who developed SCA2 at age 80 years. $^{8}$

Cerebellar ataxia with neuropathy and vestibular areflexia syndrome causes late-onset disease and was recently shown to be associated with biallelic intronic repeat expansions in RFC-1. Heterozygous expansions are overrepresented in patients with undiagnosed ataxia compared with control populations. ${ }^{9}$

In summary, our patient's phenotype of parkinsonism, cerebellar ataxia, and neuropathy is most similar to that seen in SCA2. Furthermore, a SCA2 phenotype has been reported in association with long-normal CAG expansions in $A T X N 2^{8}$ but at a much later age at onset. Parkinsonism is well described in VCP variants; however, the VCP R159C variant alone does not explain her ataxic symptoms. ${ }^{1}$ Our patient's heterozygous intronic AAGGG repeat expansion in RFC-1 does not explain her age at onset or parkinsonism. ${ }^{9}$ We speculate that the phenotype of her long-normal ATXN2 expansions has been modified by her pathogenic $V C P$ variant and heterozygous expansion in RFC-1. Although no direct interactions between any of these proteins have been reported, ${ }^{10}$ VCP and ataxin-2 protein mutations are strongly associated with pathologic accumulation of TDP-43..$^{1-3,5-7}$ It is important to counsel our patient that she could still develop typical symptoms of her $V C P$ variant (myopathy, $\mathrm{PDB}$, and FTD) as the disease progresses. This combination of a VCP variant, longnormal biallelic CAG repeats in ATXN2, and heterozygous intronic AAGGG repeat expansion in RFC-1 has not been reported previously. This case illustrates the potential for interactions between genes associated with neurodegeneration and their role in the pathogenesis of new phenotypes.

\section{Acknowledgment}

The authors thank Christopher Gomez, MD, PhD (University of Chicago, IL), for providing ataxia exome and RFC-1 expansion data and discussing the case.

\section{Study Funding}

The authors report no targeted funding.

\section{Disclosure}

The authors report no disclosures relevant to the manuscript. Full disclosure form information provided by the authors is available with the full text of this article at Neurology.org/NG.

\section{Publication History}

Received by Neurology: Genetics November 23, 2020. Accepted in final form March 18, 2021.

Appendix Authors

\begin{tabular}{lll}
\hline Name & Location & Contribution \\
\hline $\begin{array}{l}\text { Alana E. } \\
\text { Kirby, MD, } \\
\text { PhD }\end{array}$ & $\begin{array}{l}\text { Rush University } \\
\text { Medical Center, } \\
\text { Chicago, IL }\end{array}$ & $\begin{array}{l}\text { Interpreted the data and drafted } \\
\text { the manuscript for intellectual } \\
\text { content }\end{array}$ \\
$\begin{array}{l}\text { Virginia } \\
\text { Kimonis, } \\
\text { MD }\end{array}$ & University of & $\begin{array}{l}\text { Interpreted the data and revised } \\
\text { the manuscript for intellectual } \\
\text { content }\end{array}$ \\
\hline
\end{tabular}




\section{Appendix (continued)}

\begin{tabular}{lll}
\hline Name & Location & Contribution \\
\hline Katie & Rush University & $\begin{array}{l}\text { Interpreted the data and revised } \\
\text { Kompoliti, }\end{array}$ \\
$\begin{array}{l}\text { Medical Center, } \\
\text { Chicago, IL }\end{array}$ & \begin{tabular}{l} 
content \\
\hline
\end{tabular} \\
\hline
\end{tabular}

\section{References}

1. Al-Obeidi E, Al-Tahan S, Surampalli A, et al. Genotype-phenotype study in patients with valosin-containing protein mutations associated with multisystem proteinopathy. Clin Genet. 2018;93(1):119-125.

2. Chan N, Le C, Shieh $\mathrm{P}$, et al. Valosin-containing protein mutation and Parkinson's disease. Parkinsonism Relat Disord. 2012;18(1):107-109.

3. Spina S, Van Laar AD, Murrell JR, et al. Phenotypic variability in three families with valosin-containing protein mutation. Eur J Neurol. 2013;20(2):251-258.
4. $\quad$ Pulst SM. The complex structure of ATXN2 genetic variation. Neurol Genet. 2018; 4(6):e299.

5. Neuenschwander AG, Thai KK, Figueroa KP, Pulst SM. Amyotrophic lateral sclerosis risk for spinocerebellar ataxia type 2 ATXN2 CAG repeat alleles: a meta-analysis. JAMA Neurol. 2014;71(12):1529-1534.

6. Ross OA, Rutherford NJ, Baker M, et al. Ataxin-2 repeat-length variation and neurodegeneration. Hum Mol Genet. 2011;20(16):3207-3212.

7. Zhou X, Wang C, Ding D, et al. Analysis of (CAG)n expansion in ATXN1, ATXN2 and ATXN3 in Chinese patients with multiple system atrophy. Sci Rep. 2018;8(1): 3889.

8. Tojima M, Murakami G, Hikawa R, et al. Homozygous 31 trinucleotide repeats in the SCA2 allele are pathogenic for cerebellar ataxia. Neurol Genet. 2018;4(6): e283.

9. Syriani DA, Wong D, Andani S, et al. Prevalence of RFC-1-mediated spinocerebellar ataxia in a North American ataxia cohort. Neurol Genet. 2020;6(3); e440.

10. Chung CG, Lee H, Lee SB. Mechanisms of protein toxicity in neurodegenerative diseases. Cell Mol Life Sci. 2018;75:3159-3180. 


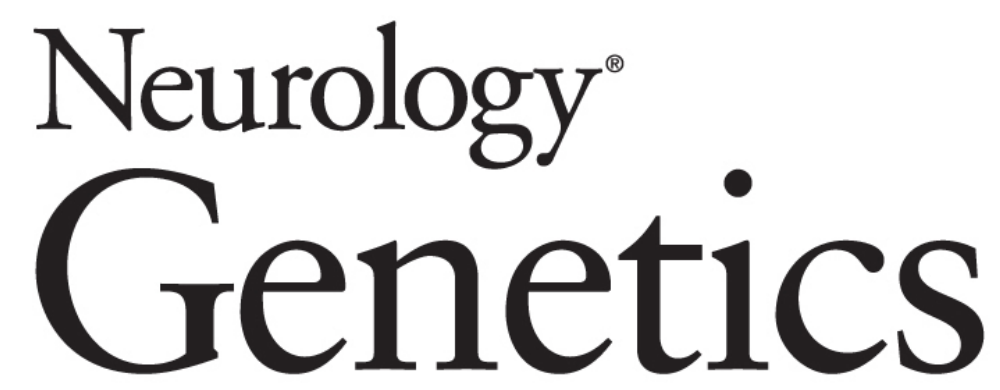

\author{
Ataxia and Parkinsonism in a Woman With a VCP Variant and Long-Normal Repeats \\ in the SCA2 Allele \\ Alana E. Kirby, Virginia Kimonis and Katie Kompoliti \\ Neurol Genet 2021;7; \\ DOI 10.1212/NXG.0000000000000595
}

This information is current as of July 8, 2021

Neurol Genet is an official journal of the American Academy of Neurology. Published since April 2015, it is an open-access, online-only, continuous publication journal. Copyright Copyright ( 2021 The Author(s). Published by Wolters Kluwer Health, Inc. on behalf of the American Academy of Neurology.. All rights reserved. Online ISSN: 2376-7839.

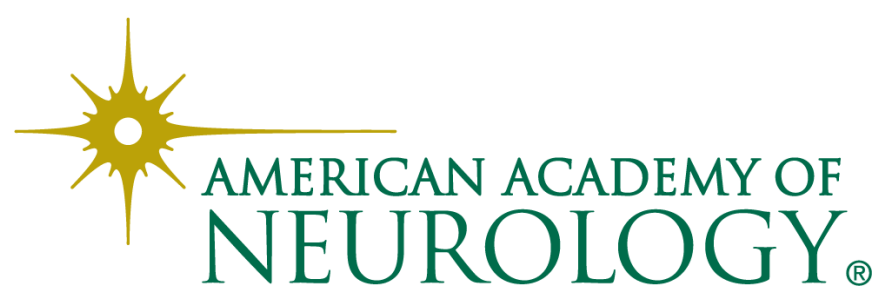




\section{Updated Information \& Services}

References

Subspecialty Collections

Permissions \& Licensing

Reprints including high resolution figures, can be found at: http://ng.neurology.org/content/7/4/e595.full.html

This article cites 10 articles, 3 of which you can access for free at: http://ng.neurology.org/content/7/4/e595.full.html\#\#ref-list-1

This article, along with others on similar topics, appears in the following collection(s):

\section{All Genetics}

http://ng.neurology.org//cgi/collection/all_genetics

Gait disorders/ataxia

http://ng.neurology.org//cgi/collection/gait_disorders_ataxia

Parkinson's disease/Parkinsonism

http://ng.neurology.org//cgi/collection/parkinsons_disease_parkinsonis $\mathrm{m}$

Peripheral neuropathy

http://ng.neurology.org//cgi/collection/peripheral_neuropathy Spinocerebellar ataxia

http://ng.neurology.org//cgi/collection/spinocerebellar_ataxia

Information about reproducing this article in parts (figures,tables) or in its entirety can be found online at:

http://ng.neurology.org/misc/about.xhtml\#permissions

Information about ordering reprints can be found online:

http://ng.neurology.org/misc/addir.xhtml\#reprintsus

Neurol Genet is an official journal of the American Academy of Neurology. Published since April 2015, it is an open-access, online-only, continuous publication journal. Copyright Copyright $\odot 2021$ The Author(s). Published by Wolters Kluwer Health, Inc. on behalf of the American Academy of Neurology.. All rights reserved. Online ISSN: 2376-7839.

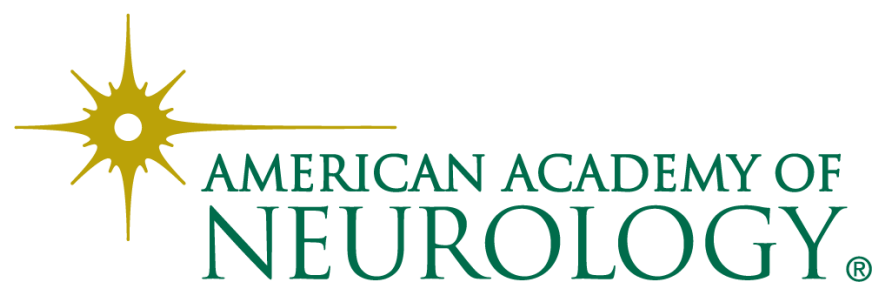

